\title{
ANTITRUST PERSPECTIVES FOR DURABLE-GOODS MARKETS
}

\author{
MICHAEL WALDMAN
}

\section{CESIFO WORKING PAPER NO. 1306}

CATEGORY 9: INDUSTRIAL ORGANISATION

OCTOBER 2004

Presented at CESifo Venice SuMmer Institute, Workshop ON

RECENT DEVELOPMENTS IN ANTI-TRUST ANALYSIS, JULY 2004

\footnotetext{
An electronic version of the paper may be downloaded

- from the SSRN website:

www.SSRN.com

- from the CESifo website:

www. CESifo.de
} 


\title{
ANTITRUST PERSPECTIVES FOR DURABLE-GOODS MARKETS
}

\begin{abstract}
Markets for durable goods constitute an important part of the economy. In this paper I first briefly review the microeconomic theory literature on durable-goods markets, focusing mostly on the last ten years. I then discuss a number of my own recent analyses concerning optimal antitrust policy in durable-goods markets that mostly build on ideas in the larger literature. Specific topics covered include: (i) optimal antitrust policy for durable-goods mergers; (ii) practices that eliminate secondhand markets; (iii) tying in markets characterized by upgrades and switching costs; and (iv) antitrust policy for aftermarket monopolization in durable-goods markets.
\end{abstract}

JEL Code: L40.

\author{
Michael Waldman \\ Johnson Graduate School of Management \\ Cornell University \\ Sage Hall \\ Ithaca, NY 14853 \\ USA \\ mw46@cornell.edu
}

I would like to thank Dennis Carlton, Ari Gerstle, Justin Johnson, and Hodaka Morita for conversations on the topics discussed in this paper. 


\section{INTRODUCTION}

Markets for durable goods constitute an important part of the economy. For example, in the US in the year 2000 personal consumption expenditures on durable goods exceeded eight hundred billion dollars. Further, in the manufacturing sector in the US in 2000 durable goods constituted roughly sixty percent of aggregate production. This importance in the economy has resulted in an extensive theoretical literature on the microeconomics of durable goods. In this paper I review the microeconomic theory literature on durable-goods markets. I then discuss a number of my own recent analyses concerning optimal antitrust policy in durable-goods markets that mostly build on ideas in the larger literature.

One might ask, why is there a literature devoted solely to the operation of durable-goods markets? The answer is that there are a number of issues that only arise in durable-goods markets or arise more frequently in such markets. For example, issues concerning secondhand or used-goods markets are important for durable goods but arise infrequently for nondurables. Another issue that arises frequently in durable-goods markets but rarely for nondurables is that of time inconsistency. That is, as first pointed out by Coase (1972), a monopolist selling a durable good in the absence of commitment does not have optimal incentives concerning actions taken after it first sells new units with the result that its own profitability can be reduced by its choice of such actions. Finally, in durable-goods markets there is the issue of product upgrades by which I mean the introduction of new products that improve on existing products or products that consumers can add on to such existing products to improve them.

From the standpoint of this paper, what is of importance is that the various issues that arise frequently in durable-goods markets but infrequently elsewhere lead to antitrust issues that are unique to durable-goods markets. For example, it has been argued by various authors such as Carlton and Gertner (1989) that in durable-goods markets the stock of used units constrains the exercise of market power by new-unit sellers with large markets shares. This leads to a question concerning optimal antitrust merger policy for durable-goods markets. That is, since the stock of used units constrains the exercise of market power in durable-goods markets, one could argue that antitrust authorities should be less concerned about mergers that increase market power in durable-goods markets. Another issue concerns aftermarket monopolization. Because durable goods have long economic lives, there is greater scope in such markets for important aftermarket products such as maintenance and other types of complementary products. In such markets durable-goods sellers frequently have the ability to stop other firms from selling aftermarket products important for its own durable units and in this way monopolize these markets. The antitrust issue is then the extent to which the antitrust authorities should prohibit this behavior.

The point of this paper is that there have been a number of recent advances in the durable-goodstheory literature that have important implications for prominent antitrust issues concerning durable goods. Consider again the issue of optimal antitrust merger policy in durable-goods markets. Carlton and 
Gertner (1989) formally analyzed this issue. They show that the existence of a stock of used units in durable-goods industries dramatically lowers the social-welfare losses associated with a merger that moves a durable-goods industry from competition to monopoly. They then conclude by arguing that the antitrust authorities should be much less concerned in durable-goods industries than in nondurable-goods industries about blocking mergers that increase market concentration. But Carlton and Gertner employ the approach to modeling durable goods made popular by Swan in the early 1970s which has an important unrealistic feature, i.e., consumers can combine a number of used units to make a perfect substitute for a new unit.

Waldman (1996a) and Hendel and Lizzeri (1999a) have developed a more realistic way of modeling durable-goods markets. In their approach each individual consumes either zero or one physical unit per period and durable-good quality decays as a unit ages, so there is no number of used units that serves as a perfect substitute for a new unit. As discussed in Section IV, Gerstle and Waldman (2004) reconsider the Carlton and Gertner analysis by employing this approach to durable-goods modeling. They show that it is still the case that an existing stock of used units limits the social-welfare losses associated with a merger that increases market power, but much less so than in the Carlton and Gertner analysis. Their conclusion is that there should be a reduced level of scrutiny by the antitrust authorities of mergers in durable-goods industries relative to nondurable-goods markets, but the size of this reduction should be significantly less than suggested by Carlton and Gertner.

Another issue I consider is that of bundling in durable-goods markets characterized by complementary goods. Because of Microsoft's tying behavior, there has been significant recent attention in the theoretical literature to tying in complementary-goods markets. Papers such as Choi and Stefanadis (2001) and Carlton and Waldman (2002) help us understand the idea that some of Microsoft's tying behavior is likely motivated by a desire to preserve its Windows monopoly. As argued in Carlton and Waldman's paper, this motivation for tying will arise when the alternative producer's complementary good, e.g., Netscape Navigator, has the potential to evolve into a substitute for Windows. But this does not explain all of Microsoft's tying behavior such as Microsoft's tying of Windows and digital media technology. In addition, Whinston (1990) shows that a monopolist of an "essential" primary good - one required for all used of the complementary good - has no incentive to tie. Given the high market share of Windows in the PC market, this leaves as a puzzle some of Microsoft's more recent tying actions.

Whinston considers a one-period model. In Section VI I discuss recent research I have been conducting with Dennis Carlton concerning tying in durable-goods markets. ${ }^{1}$ We consider a two-period durable-goods setting in which the monopolist's primary good is essential and the alternative producer

\footnotetext{
${ }^{1}$ We hope to have the paper available by the end of 2004.
} 
has a superior complementary good. Further, in the second period we allow for upgrades of the complementary good and consumer switching costs, i.e., a consumer in the second period receives higher gross utility by consuming a complementary unit produced by the same firm that produced the complementary unit the individual consumed in the first period. ${ }^{2}$ Our basic finding is that Whinston's result concerning essential primary products no longer holds. That is, even though the monopolist's primary product is essential, the firm sometimes ties in order to foreclose competition in the complementary market and in this way monopolize the complementary market. The conclusion I draw is that antitrust intervention concerning tying in complementary markets may be justified more frequently than the existing literature suggests.

As a final introductory point, it is worthwhile noting that much of the discussion concerns monopoly producers of durable goods that sell to consumers. The correct interpretation is not that these analyses only apply to such settings. First, although most durable-goods producers are not monopolists, many do have some market power and monopoly analyses should provide useful insights. Second, the problems faced by durable-goods producers selling to firms should be similar to the problems faced by durable-goods producers that sell directly to consumers. Thus, the analyses that follow should help us better understand some of the important issues faced by producers of durable intermediate products.

The outline for the paper is as follows. Sections II and III present a history of the microeconomic theory literature on durable goods. Sections IV through VII then present recent antitrust related analyses of mine which build to a great extent on ideas from the last ten years of this larger literature. Section IV concerns optimal antitrust merger policy for durable-goods markets. Section V concerns the incentive for durable-goods producers to "eliminate secondhand markets." Section VI discusses some recent ideas concerning the bundling of complementary goods. Section VII discusses antitrust policy for the monopolization of durable-goods-related aftermarkets. Section VIII presents concluding remarks.

\section{A BRIEF HISTORY OF DURABLE-GOODS THEORY - PART I}

In this section I discuss the durable-goods theory literature from the early 1970s through the early 1990s. I start with three classic contributions to this literature each of which first appeared in the early 1970s. I then discuss more broadly the literature up through the early 1990s. In the next section I discuss the last ten years of this literature. ${ }^{3}$

\footnotetext{
2 There is an extensive literature that investigates models characterized by consumer switching costs. Papers in this literature include Klemperer $(1987,1989)$ and Farrell and Shapiro $(1988,1989)$. See also the earlier work of Williamson $(1975,1985)$. Klemperer (1995) surveys the literature.

${ }^{3}$ See Waldman (2003) for a more in depth discussion of this literature
} 


\section{A) Three Classic Contributions}

The early 1970s witnessed three classic contributions to durable-goods theory. From the standpoint of today's literature, the best known of these three from the standpoint of durable-goods theory is Coase's (1972) analysis of time inconsistency. Because Coase's initial analysis was informal, I will start by discussing Bulow's (1982) formalization of the idea. Consider a durable-goods monopolist operating in a two-period setting in which units are perfectly durable and the monopolist must choose an output level for each period. The basic time-inconsistency problem is that the commitment and noncommitment outcomes are different. That is, if in the first period the monopolist is unable to commit to an output level for the second period, then the monopolist sells "too much" in the second period with a resulting decrease in overall monopoly profitability. The decrease occurs because consumers in the first period anticipate this behavior in the second period, and are thus willing to pay less for new units in the first period than in the commitment case in which the firm sells fewer second-period new units.

As indicated, what I have described is not actually the argument in Coase's initial paper, but rather the formalization of Coase's idea that appears in Bulow (1982). What Coase actually argued, called the Coase conjecture, is that a durable-goods monopolist selling a perfectly durable good in an infinite-period setting will not be able to exercise any market power. That is, because consumers anticipate that the price will quickly fall to marginal cost due to time inconsistency, even in the first period consumers will be unwilling to pay more than marginal cost so the equilibrium is marginal-cost pricing in every period. The other main part of Coase's argument is that leasing or renting avoids the problem. The logic here is that time inconsistency arises when the monopolist sells its output because the monopolist does not take into account in later periods how current output decisions affect the value of units previously sold. Since leasing means that in those later periods the monopolist owns those previously produced units, under leasing there is no externality and thus time inconsistency is avoided.

The second classic contribution of the early 1970s is the analysis of optimal durability choice that appeared in a series of papers by Swan (see Swan (1970,1971) and Sieper and Swan (1973)). In the late 1960s and early 1970s a number of authors argued that a durable-goods monopolist would choose a durability level below the first-best efficient level (see Kleiman and Ophir (1966), Levhari and Srinivasan (1969), and Schmalensee (1970)). Swan showed that these authors were in fact incorrect, or, in other words, in the type of setting considered by these authors a durable-goods monopolist would choose the socially-optimal level of durability.

To understand Swan's argument, consider a durable-goods monopoly setting in which consumers value "service units," and from the standpoint of current consumption a unit, whether new or used, can be described as some number of service units (this way of modeling durable goods dates back to Wicksell (1934)). Further, assume depreciation simply means that the number of service units contained in a single 
physical unit declines as the unit ages, where durability controls the speed of decline. Now think about monopoly behavior in the steady state. Since consumers only care about the service units consumed in any period, the monopolist chooses output and durability such that the steady-state number of service units is produced at minimum cost. In other words, although the standard monopoly distortion means the firm produces less than the socially-optimal steady-state number of service units, there is no distortion in terms of durability since the monopolist produces this number at minimum cost. But this is the same as saying that, taking as fixed the steady-state number of service units available per period, the monopolist chooses the socially-optimal-durability level, and also that, in many cases, it makes the same durability choice as would a competitive industry.

The last classic contribution to durable-goods theory of the early 1970s is the seminal analysis of Akerlof (1970) concerning adverse selection or the market for lemons. This paper is clearly recognized as one of the seminal papers that launched the asymmetric-information revolution in economics, but it has not traditionally been described as an important contribution to durable-goods theory. However, given that the main analysis in that paper concerns the secondhand market for a durable good, the paper in fact has important implications for durable-goods markets.

Although I am sure that all the readers know the argument, let me repeat it here briefly. In Akerlof's model there are sellers each of whom owns a single used car, where cars vary in quality and each seller knows the quality of his or her own car. There are also buyers each of whom does not initially own a used car, where each buyer does not know the quality of any specific used car but rather only knows the quality of the used car offered for sale. The other key assumption is that buyers value cars more than sellers so full information requires all cars are traded. The main point of the analysis is that under asymmetric information not all cars are traded. The reason is that the information asymmetry means that the secondhand-market price for any specific used car reflects the average quality of the cars offered for sale so potential sellers with high quality used cars keep them rather than sell them. ${ }^{4}$

\section{B) The 1970s Through the Early 1990s and Overview}

Proceeding chronologically, let me begin this subsection by focusing on the 1970s. The durablegoods literature of the 1970s was primarily focused on Swan's results (see Schmalensee (1979) for a survey). This literature considered relaxing various assumptions of the basic Swan framework. For example, Barro (1972) allowed firms and consumers to have different discount rates, Schmalensee (1974) and $\mathrm{Su}$ (1975) introduced a maintenance decision on the part of consumers, while Auernheimer and

\footnotetext{
${ }^{4}$ In Akerlof's analysis there is no trade under asymmetric information. But this result is due to specific assumptions he made concerning the relative valuations of buyers and sellers, rather than the result being a general property of such models.
} 
Saving (1977) allowed for short-run nonconstant returns to scale. The bottom line is not surprising. Relaxation of certain assumptions causes durability choice to remain efficient while relaxation of other assumptions results in inefficiency. Note here that certain parts of this literature are a bit confusing because a demonstration that monopoly and competitive durability levels are different and a showing of inefficiency are not the same. That is, a demonstration that a monopolist chooses different durability than a competitive industry does not mean that durability is inefficient (or at least not second-best efficient). The reason is that, since output varies across the two cases, the second-best efficient durability choice can be different for monopoly and competition.

What I find surprising about this literature is that very little attention was paid to what seems to me the most questionable assumption in Swan's approach. As discussed earlier, in Swan's approach a unit can be defined as a number of "service units" which means that it is always possible to combine a number of used units to create a perfect substitute for a new unit. Although the assumption has advantages from a tractability standpoint, it is clearly unrealistic. For most real-world durable-goods markets, such as the markets for automobiles, refrigerators and toasters, a consumer cannot combine a number of used units to create a perfect substitute for a new unit. In these markets, instead, new and used units vary in quality, and ownership of a new unit provides utility from consumption that cannot be matched by any number of used units. As will be discussed in the next section, relaxation of this assumption clearly changes Swan's conclusion that monopoly durability choice is socially optimal.

Whereas the 1970s focused on Swan's contribution, the 1980s and early 1990s focused on Coase's contribution. Bulow $(1982,1986)$ formalized the basic idea of time inconsistency in durablegoods-monopoly output choice, where his focus was simple settings in which the logic of the idea is easy to see. In addition to showing the existence of a time-inconsistency problem that can be avoided by leasing, Bulow in his second paper showed that time inconsistency can result in a durable-goods monopolist building less than the socially optimal level of durability into its output. The logic is that, because of time inconsistency, the monopolist is hurt by the durable nature of the product so reducing durability is a way to reduce the loss in profits due to time inconsistency.

The rest of this literature focused on three topics. The first was whether the Coase conjecture is correct, i.e., would a durable-goods monopolist operating in an infinite-period setting drop price to marginal cost almost immediately. This idea was investigated in a number of papers including Stokey (1981), Gul, Sonnenschein, and Wilson (1986), and Ausubel and Deneckere (1989). There are two main related results here. The first is, if buyers' strategies do not depend on past behavior so reputation formation by the firm is not possible, then Coase is correct as long as the consumer valuation distribution exhibits no gaps, i.e., the valuation of the lowest valuation consumer is less than or equal to the firm's marginal cost. The second result which is contained in Ausubel and Deneckere's analysis is, if buyers' 
strategies can depend on past behavior so reputation formation is possible, then even retaining the no-gap assumption there are equilibria in which the monopolist regains some or all of its market power.

The other two issues considered are the robustness of Coase's results to changes in his assumptions, and tactics that the firm can employ to avoid the time-inconsistency problem. In terms of the first issue, Bond and Samuelson (1984) show that depreciation and replacement sales serve to ameliorate time inconsistency, Kahn (1986) in a similar vein shows that time inconsistency is reduced if the monopolist's marginal cost is upward sloping rather than constant, while Bagnoli, Salant, and Swierzbinski (1989) and Levine and Pesendorfer (1995) consider how the analysis changes when output is discrete. In terms of the second issue, as already discussed Bulow (1986) shows the monopolist can reduce time inconsistency by reducing durability, Butz (1990) shows that contractual provisions such as best-price provisions can be used to avoid the problem, while Karp and Perloff (1996) investigate the extent to which the monopolist can avoid the problem by employing an inferior high-cost technology. ${ }^{5}$

As a final point, although I feel that Coase's insight that a durable-goods monopolist faces a timeinconsistency problem is one of the fundamental insights concerning durable-goods markets, I also feel that his and others' focus on time inconsistency concerning output choice was somewhat misplaced. Consistent with Butz's analysis, contractual commitments concerning future outputs and prices is frequently feasible (and it is also frequently possible to establish a reputation concerning price). Hence, my feeling is that the specific time-inconsistency problem identified by Coase is infrequently observed in real-world markets, although knowledge of the problem can help us better understand real-world contractual provisions used to avoid the problem. In contrast, I believe there are other choice variables such as R\&D expenditures and new-product introductions for which contracting is much more difficult, and thus time inconsistency concerning these variables is much more likely to be observed in real-world markets. Some possibilities along this line are discussed in later sections.

\section{A BRIEF HISTORY OF DURABLE-GOODS THEORY - PART II}

In Section II I described durable-goods theory from roughly 1970 through the early 1990s. In this section I describe the important contributions to durable-goods theory over roughly the last ten years. I focus on three lines of research: i) development of a more realistic approach to modeling durability choice; ii) models of new-product introductions; and iii) exploring the role of adverse selection in durable-goods markets. The main point of the discussion is that, whereas the literature up through the early 1990s developed some important key insights concerning durable-goods markets but was somewhat

\footnotetext{
${ }^{5}$ More recently, Morita and Waldman (2004) show that time inconsistency can be avoided if the firm monopolizes the maintenance market for its own product, where the logic here is similar to the original leasing result.
} 
lacking in terms of the realism of the main models analyzed, the last ten years of research has built on those earlier key insights to build much more realistic models of durable-goods markets.

As discussed in the previous section there is a significant drawback with the Swan approach to modeling durability which is that for most real-world durable products a consumer cannot combine a number of used units to create a perfect substitute for a new unit. Recent papers have focused on this drawback and developed an alternative approach based on the classic monopoly product-line-pricing analysis of Mussa and Rosen (1978). I will first discuss that paper and then discuss how these recent papers have adapted that analysis for the modeling of durable-goods markets.

Mussa and Rosen consider a single-period monopoly model in which the monopolist sells new units of varying quality levels to consumers who vary in terms of their valuation for quality. They additionally assume that the monopolist does not know each individual's valuation for quality, but does know the distribution of these valuations in the population. Their main result concerns the quality levels the firm sells to the various groups. In particular, for the high-valuation group the monopolist sells the first-best efficient quality level, but for lower valuation groups the monopolist sells quality levels that are below the first-best levels. The reason is that a higher valuation group always has the option of choosing the quality level the firm is selling to a lower valuation group. This, in turn, links the prices in such a way that the firm has an incentive to reduce the qualities sold to lower valuation groups below the efficient levels because of the resulting increases in the prices of higher quality units.

Waldman (1996a) and Hendel and Lizzeri (1999a) develop an approach to durable-goods modeling closely related to the Mussa and Rosen framework (see also Kim (1989) and Anderson and Ginsburgh (1994)). In their approach each individual consumes either zero or one physical unit per period, where the quality of a unit declines as the unit ages. The fact that each individual consumes either zero or one physical unit per period means that this approach is not subject to the same criticism as the Swan approach concerning the ability to combine used units to create a perfect substitute for a new unit. The other key assumptions are that consumers vary in terms of their valuations for product quality, that durability choice is the speed at which used units deteriorate in quality, and that there is a frictionless secondhand market on which used units can be traded.

These two papers demonstrate that models along this line are similar in many respects to the Mussa and Rosen analysis just described. ${ }^{6}$ For example, one result that comes out of this type of model is that, in contrast to what was true in Swan's approach to modeling durable goods, a durable-goods monopolist chooses a durability level below the socially-efficient level, where the logic for this result is similar to why in the Mussa and Rosen analysis lower valuation individuals are sold quality levels below

\footnotetext{
${ }^{6}$ Waldman (1996a) discusses in detail the similarities between this approach to modeling durable goods and the Mussa and Rosen product-line-pricing analysis.
} 
the efficient levels. That is, similar to the Mussa and Rosen analysis, in each period there is a linkage between the prices of high- and low-quality units (or equivalently, new and used units), and this linkage provides the monopolist with an incentive to distort the quality consumed by low-valuation groups down in order to increase the price for high-quality or new units. In turn, the way the monopolist accomplishes this is by reducing durability below the first-best level.

The second recent innovation I will describe is the recent emphasis on models concerning newproduct introductions such as found in Waldman (1993,1996b), Choi (1994), Fudenberg and Tirole (1998), Lee and Lee (1998), Ellison and Fudenberg (2000), Fishman and Rob (2000), and Nahm (2004). Clearly, new-product introductions are an important part of many real-world durable-goods markets. By focusing on new-product introductions, these recent papers have been able to address various aspects of real-world durable-goods markets that previous literature had ignored or had not sufficiently emphasized.

One topic that has received significant attention is that of pricing in durable-goods markets given new-product introductions. Of the papers that have focused on this issue, the most important is Fudenberg and Tirole's paper. In their two-period model units are perfectly durable, but new units in the second period are of higher quality than used units. They also assume that consumers vary in terms of their valuations for quality. Although there is no durability choice here and products do not deteriorate as they age, there is a close relationship here with the Mussa and Rosen product-line pricing analysis as is the case for the durability analyses just described. As a result, Fudenberg and Tirole show the same type of linkage between new- and used-unit prices as found in those durability analyses. In addition to demonstrating this linkage, Fudenberg and Tirole also demonstrate a number of implications of this linkage to issues such as the use of trade-ins and buybacks in firms' marketing strategies (see Section V for a discussion related to their buyback result).

The other main issue that has been investigated here is planned obsolescence or equivalently time inconsistency concerning new-product introductions (see, for example, Waldman (1993,1996b), Choi (1994), Ellison and Fudenberg (2000), and Nahm (2004)). Earlier papers such as Swan (1972) and Bulow (1986) discuss the issue of planned obsolescence from the standpoint of durability choice, but as Bulow states "...planned obsolescence is much more than a matter of durability, it is also and perhaps primarily about how oftern a firm will introduce a new product and how compatible the new product will be with older versions..." (Bulow (1986), p. 747) The recent papers listed above follow Bulow's suggestion of defining planned obsolescence in terms of new-product introductions, and show how Coase's initial insight concerning output choice can be used to provide a theory of planned obsolescence.

Coase's initial insight described broadly is that in later periods a durable-goods monopolist has an incentive to take actions that lower the value of units it previously sold and these actions serve to lower the firm's overall profitability. These recent papers apply this idea to new-product introductions and 
show that, both in terms of compatibility choice and quality improvement, a durable-goods monopolist sometimes has an incentive to introduce new products that lower the value of units it previously sold and this lowers the firm's overall profitability. Also, similar to what was true in analyses of the original Coase time-inconsistency problem, the time-inconsistency problem concerning new-product introductions can typically be avoided by leasing rather than selling output. ${ }^{7}$

The last recent innovation in the durable-goods theory literature I will describe is the recent literature that further investigates the role of adverse-selection in durable-goods markets. As discussed in Section II, in my view Akerlof's (1970) seminal analysis of adverse selection and asymmetric information is also a classic contribution to durable-goods theory. However, although I feel this position is easy to justify, the paper's implications for durable-goods markets was basically ignored for almost thirty years. Only recently have papers such as Hendel and Lizzeri (1999b,2002) and Johnson and Waldman (2003) started to further investigate the durable-goods implications of Akerlof's argument.

One drawback of Akerlof's original analysis is that it is a very partial analysis in that it focuses on the secondhand market and completely ignores the market for new units. Hendel and Lizzeri (1999b) address this issue by considering an asymmetric-information durable-goods model which incorporates both new- and used-goods markets. Their main result is that adverse selection continues to be important even after the new-unit market is incorporated into the analysis. The other main result is that the model captures a richer picture of why secondhand trade is efficient than is found in Akerlof's analysis. In Akerlof's analysis it is directly assumed that used-unit buyers have higher valuations for used units than sellers and so trade is efficient. Hendel and Lizzeri enrich this view by incorporating the new-unit market. In Hendel and Lizzeri's analysis each individual has a valuation for a single unit that depends on the unit's quality. The result is that high-valuation consumers buy new units and sell used units to lowvaluation consumers. The way to interpret this is that as in Akerlof's analysis buyers have higher valuations for the used units than sellers, but now it is the "net" valuations that are higher, i.e., the valuations for used units taking into account the possibility of buying a new unit of output.

More recently, Hendel and Lizzeri (2002) and Johnson and Waldman (2003) have shown that this approach can be employed to provide an explanation for leasing in the new-car market. Although Hendel and Lizzeri focus on a monopoly model while Johnson and Waldman consider competition, both papers rely on basically the same argument. The argument in both cases is that adverse-selection inefficiency arises because of the presence of asymmetric information in the secondhand market, so leasing in the new-car market avoids the inefficiency because with leasing used cars are returned to the manufacturers and the manufacturers have no private information. This results in leasing in the monopoly case because

\footnotetext{
${ }^{7}$ One can also construct a theory of planned obsolescence and new-product introductions using an analysis closely related to the durability discussion earlier in this section. See Section V for a discussion.
} 
avoiding inefficiency increases consumer willingness to pay which, in turn, increases monopoly profitability, while in the competitive case there is leasing because competition causes firms to market their products in the manner that reduces inefficiency. In addition to showing this basic argument, both the Hendel and Lizzeri analysis and the Johnson and Waldman analysis show that this approach explains various features of real-world new- and used-car markets. ${ }^{8}$

\section{OPTIMAL MERGER POLICY FOR DURABLE-GOODS MARKETS}

An important antitrust issue concerning durable-goods markets is that of the optimal policy concerning mergers. The reason that optimal merger policy might be different for durable-goods industries than for nondurable-goods industries is the presence of a stock of used units that exists at any point in time in durable-goods industries. As has been argued previously by others, this existing stock potentially constrains the exercise of market power after a merger and this, in turn, should have implications for optimal antitrust policy concerning mergers. In this section I first briefly discuss the classic analysis of Carlton and Gertner (1989) concerning this issue, and then discuss in more detail the recent analysis that appears in Gerstle and Waldman (2004).

The classic analysis on this topic is the paper by Carlton and Gertner. ${ }^{9}$ They consider a durablegoods setting in which there is a merger at some point in time that transforms a competitive industry into a monopoly, and then a number of periods later unanticipated entry moves the industry back to competition. Their focus is on a comparison of the social-welfare loss associated with this scenario with the social-welfare loss associated with the same scenario in a nondurable-goods industry. They show that for reasonable parameterizations the social-welfare loss in the durable-goods case is a small fraction of the loss in the analogous nondurable-goods setting. For example, assuming a slow depreciation rate of .95 and entry after five periods yields that the deadweight loss in the durable-goods case is two percent of the deadweight loss in the nondurable-goods case. Their conclusion is that in durable-goods industries the existing stock of used units constrains the existence of market power so much after a merger that the antitrust authorities need worry little about mergers in durable-goods industries.

Gerstle and Waldman (2004) reconsiders this issue. Carlton and Gertner employ the approach to modeling durable goods popularized by Swan in the early 1970s. As discussed in Sections II and III, there is a drawback with that approach. Briefly, in the Swan approach to modeling durable goods, a unit, whether new or used, is equivalent to some number of "service units," so in that type of world it is always possible to combine a number of used units to create a perfect substitute for a new unit. Although

\footnotetext{
8 Johnson and Waldman (2004) extend their earlier analysis by incorporating moral hazard and show that this allows the analysis to even better match the evidence concerning real-world new- and used-car markets.

${ }^{9}$ Other papers on the topic include Froeb (1989) and Reitman (2001).
} 
appealing from a tractability standpoint, the problem is that it is clearly unrealistic in the sense that in most durable-goods markets such as those for automobiles, refrigerators, and toasters it is not possible to combine a number of used units to create a perfect substitute for a new unit. In my paper with Gerstle, instead of employing the Swan approach to durable-goods modeling, we employ the approach to durablegoods modeling developed in Waldman (1996a) and Hendel and Lizzeri (1999a) which was discussed in detail in Section III. In that approach new and used units vary in terms of quality and each individual consumes either zero or one physical unit per period. One important feature of modeling durable goods in this way is that used units cannot be combined to create a perfect substitute for a new unit.

We redo the basic Carlton and Gertner analysis using this alternative approach to modeling durable goods. That is, we investigate what happens when a competitive situation is transformed into a monopoly by merger, and then a number of periods later unanticipated entry moves the industry back to competition. Also, our focus is on a comparison of the the social-welfare loss associated with this scenario with the social-welfare loss associated with the same scenario given nondurable goods. What we show is that modeling durability in this alternative fashion in some respects yields similar results to those found in the Carlton and Gertner analysis, while in other respects the results are quite different.

To be precise, we find two main results. First, if entry occurs a small number of periods after the merger, then consistent with Carlton and Gertner's analysis we find that the social-welfare loss associated with merger to monopoly in the durable-goods case is significantly smaller than the social-welfare loss in the analogous nondurable-goods case. However, although it is smaller than in the analogous nondurablegoods case, it is significantly larger than in the Carlton and Gertner analysis. For example, focusing on the same parameterizations discussed above in which in Carlton and Gertner's analysis the social-welfare loss given durable goods was two percent of the social-welfare loss in the analogous nondurable-goods case, we find a figure of roughly fifteen percent. Similarly, for the same parameterization we decrease the depreciation rate to .9 and show that in the Carlton and Gertner approach the figure increases to eight percent while in our approach the figure increases to thirty percent.

The second main result is that an increase in the number of periods till unanticipated entry takes place causes the social-welfare loss in the durable-goods case to get closer to the social-welfare loss in the analogous nondurable-goods case. For example, starting with the parameterization mentioned above in which in our model the durable-goods loss was roughly fifteen percent of the nondurable-goods loss given entry after five periods, we find that this figure goes up to roughly thirty-three percent given entry after ten periods, up to roughly fifty percent given entry after fifteen periods, and up to roughly eighty percent given entry after one-hundred periods. Also, we find that for some parameterizations, if the number of periods till entry is sufficiently high, the durable-goods loss can even exceed the analogous nondurable-goods loss. Note that qualitatively the comparative static result on this parameter is the same 
as in the Carlton and Gertner analysis, i.e., in their approach it is also the case that increasing the number of periods till entry occurs moves the social-welfare loss in the durable-goods case closer to the socialwelfare loss in the analogous nondurable-goods case. But in the Carlton and Gertner analysis the two figures are far apart for a much broader set of parameterizations than in our analysis.

The obvious question is, what is driving the different results between our analysis and Carlton and Gertner's, and the answer is the difference in the basic approach to modeling durable goods. As stated, Carlton and Gertner employ the Swan approach which has the property that consumers can combine used units to create a perfect substitute for a new unit. Suppose in that world depreciation is slow and the merger to monopoly is followed by entry after a few periods. Any consumer with a high valuation for the durable product will either purchase a new unit or combine used units to consume the equivalent of a new unit. The result is that the social-welfare loss comes solely from consumers who receive little surplus from consuming under competition and do not consume the good during the monopoly periods. Since these consumers derive little surplus from consuming during competition, the aggregate loss from having these individuals not consume during the monopoly periods is small.

Now consider what happens in our model when depreciation is slow and the merger to monopoly is followed by entry after a few periods. In contrast to what happens in the Carlton and Gertner model, it is not just the individuals who receive little surplus under competition who are affected. Rather, because each individual is restricted to consuming a single physical unit per period, when the monopolist exercises its market power by decreasing output below the competitive level the result is that individuals scattered throughout the valuation distribution wind up consuming older and thus lower quality units than they consume under competition. This, in turn, is exactly why we find a larger social-welfare loss than is found in the Carlton and Gertner analysis. Rather than the aggregate loss being due to no consumption by individuals who receive little surplus from consumption under competition to begin with, in our model many individuals some of whom with very high valuations for the product are hurt either because they do not consume or consume a unit of lower quality than they would under competition.

Note that we believe our analysis makes sense not just because the modeling approach is more realistic than the Swan approach, but also because the outcome is more realistic in terms of who is hurt by a merger that increases market power. As stated above, in the Carlton and Gertner analysis the socialwelfare loss comes solely from low-valuation individuals who consume the good under competition but not under monopoly. But suppose, for example, that all of the world's automobile manufacturers were, in fact, to merge, and then the merged firm exercised its market power by reducing output. In contrast to the Carlton and Gertner analysis, the resulting social-welfare loss would not just come about because of lowvaluation individuals who wind up without a car. Rather, there would also be a loss because of higher valuation individuals who wind up consuming older and thus lower quality cars than they would have in 
the absence of any mergers. In other words, the social-welfare loss would look much more like the loss in our analysis than the loss in Carlton and Gertner's analysis.

Let me end the section by briefly discussing the antitrust implications of the analysis. I believe there are three main points. First, the analysis supports the Carlton and Gertner view that, because the presence of an existing stock of used units limits the exercise of market power after a merger, the antitrust authorities need to be less concerned with mergers that increase market power in durable-goods industries. Second, since we find social-welfare losses due to mergers in durable-goods industries to be much closer to the losses in nondurable-goods industries than do Carlton and Gertner, the reduction in scrutiny for durable-goods industries suggested by our analysis is much smaller than that suggested by Carlton and Gertner's analysis. Third, because our results indicate that the social-welfare loss associated with a merger in durable-goods industries is closer to the nondurable-goods social-welfare loss when future entry is likely to be slow, we would emphasize more than Carlton and Gertner the importance of expected speed of entry in judging whether or not a durable-goods merger should be allowed.

\section{V. "ELIMINATING” SECONDHAND MARKETS}

A classic antitrust issue concerning durable goods is whether a new-unit seller would ever have an incentive to "eliminate" the secondhand market for its own product. One complication concerning this issue is that the term "eliminate" could have a variety of meanings in this context. For example, it could mean that the firm prohibits the trade of used units, or it could mean that it behaves in a manner that makes used units unavailable for consumption. Although both issues are of potential real-world importance and from a theory standpoint they can be closely related, my belief is that the latter issue comes up more frequently in real-world cases so I will focus the discussion on that issue.

Until recently the standard thinking on this issue was due to Swan (1980). Swan's argument was that since the new-unit price reflects the expected prices that the unit will sell for on the secondhand market in future periods, a new-unit seller has no incentive to behave in a manner that makes used units unavailable for consumption. For example, in his 1980 article Swan states that "Clearly it is not the existence of a secondhand market per se which need imply any restraint on the profitability or the pricing decision of a monopolist...the pure monopolist selling such a durable item as an automobile is paid an amount which reflects the net present value of the stream of automobile services to possibly a whole host of future owners. Competitive secondhand auto dealers (or scrap merchants and recyclers in the case of aluminum) can then buy and sell the item indefinitely without in any way restricting the power of the monopolist as the original seller." 
In Waldman (1997) I show that this logic is incorrect (see also Waldman (1996a) and Hendel and Lizzeri (1999a)). ${ }^{10}$ My argument builds on the approach to modeling durable goods discussed in Section III in which consumers cannot combine a number of used units to create a perfect substitute for a new unit. Suppose that, as is discussed in Section III, in each period each individual consumes either zero or one physical unit of the product, a unit's quality deteriorates as the unit ages, and consumers vary in terms of their valuation for quality. Further, suppose that the new-unit seller has market power because, for example, the firm is a monopolist. Then, as I show in my 1997 paper, the firm will sometimes have an incentive to behave in a fashion that makes used units unavailable for consumption. For example, a newunit seller may use a lease-only policy and then scrap the used units that are returned.

The basic logic here is closely related to the analysis of durability choice discussed in Section III. There it was argued that in this type of model a new-unit seller with market power will have an incentive to reduce durability below the socially-optimal level because the resulting decrease in used-unit quality allows the firm to charge a higher price for new units in later periods. There are two ways this result can translate into the new-unit seller wanting to behave in a fashion that makes used units unavailable for consumption. First, if in the argument just given the incentive for a new-unit seller to reduce used-unit quality is sufficiently strong, i.e., optimal used-unit quality equals zero, then we immediately get the result that the firm has an incentive to make used units unavailable for consumption. Second, the newunit seller may have limited ability to change the production process in a manner that lowers used-unit quality without reducing new-unit quality. In such a case the firm might have an incentive not to directly reduce the durability built into new units, but rather market the product in a way that allows the firm to make functional used units unavailable for consumption.

There are a number of ways that a firm could make functional used units unavailable for consumption. One way is the practice of lease-only mentioned earlier that was a major focus of the 1953 United Shoe Machinery Case in the US and which was the focus of my 1997 paper. ${ }^{11}$ The basic idea is

\footnotetext{
${ }^{10}$ A similar argument appears in earlier papers such as Benjamin and Kormendi (1974), Miller (1974), Liebowitz (1982), and Levinthal and Purohit (1989). Those papers start by specifying demand functions and show that, given certain assumptions concerning how the demand for new units is affected by the availability of used units, a durable-goods seller could have an incentive to behave in a manner that makes used units unavailable for consumption. But this leaves as an open question whether such a demand specification is a reasonable one. In contrast, my paper starts with utility functions and production functions and shows that indeed such a demand specification is reasonable.

11 There are a number of alternative explanations for United's lease-only practice. For example, Posner (1976) suggests that the behavior was a response to the time-inconsistency argument put forth originally by Coase (see the discussion in Section II). However, as pointed out by DeGraba (1994), avoiding the Coase time-inconsistency problem requires short-term leases, so given United employed seventeen-year leases it does not seem that the Coase argument is the correct one in this case. Another perspective is put forth in Wiley, Rasmusen, and Ramseyer (1990) and Masten and Snyder (1993) which both ignore the monopoly aspect of the case and put forth efficiency rationales more consistent with a competitive market. However, since the practice is not widely observed but has
} 
that the firm offers to lease and refuses to sell new units of output, and then makes used units unavailable for consumption by scrapping the used units when they are returned. Note that one question that arises concerning this practice is why is lease-only required, i.e., why can't the firm achieve the same result by selling its output and repurchasing and scrapping used units. As I show in my 1997 paper, the problem with this alternative strategy is that it is time inconsistent. That is, in the leasing strategy the firm does not need to commit to scrap the used units when they are returned because scrapping is optimal at that point in time. In contrast, the repurchase strategy is not time consistent, i.e., at the repurchase date the firm has an incentive not to repurchase, so given any limit on commitment ability such as would be the case given a positive probability of bankruptcy, lease-only will be preferred over sales and repurchases.

Another example of a practice firms employ to make used units unavailable for consumption occurs in the textbook market. In that market firms kill off the secondhand market through the frequent introduction of new editions which make used copies nearly worthless. One might object that the above analysis is one in which new-unit sellers have significant market power, but the textbook market is one typically with many sellers so market power is limited. But this argument misses an important feature of that market. There may be significant competition in terms of the professor choosing which textbook to use for his or her course. However, once the professor has made a choice, the publisher is basically in a monopoly position in terms of selling copies to students so the above argument is quite applicable. ${ }^{12}$

The antitrust issue here is whether the antitrust authorities should intervene to eliminate practices that serve to make used units unavailable for consumption. The perspective put forth here is that the answer is frequently yes. According to the argument here such practices serve to eliminate the consumption of low-quality used units by low-valuation consumers so that the firm can raise the price for new units. The result is a reduction in social welfare in that there is no social-welfare benefit, but a social-welfare loss due to the low-quality units not being consumed. Thus, the analysis supports the US antitrust authorities' behavior in cases concerning United Shoe, IBM, and Xerox where the authorities stopped the firms from pursuing lease-only policies. ${ }^{13}$

been observed in a few cases of firms with significant market power (United Shoe, IBM, and Xerox), I find this perspective unconvincing.

12 As I argued in Waldman (1993) (see the related discussion in Section III), another possible explanation for the frequent introduction of new editions in the textbook market is that it is the result of a time-inconsistency problem that new-unit sellers face in terms of the introduction of new products. In contrast to the argument above, in this argument the practice hurts rather than helps the firm's profitability. Given that textbook publishers are in the market for many periods and so can establish a reputation for how frequently they introduce new editions, I now believe that this time-inconsistency argument is not the correct explanation for the frequent introduction of new editions in the textbook market.

${ }^{13}$ In 1953 the courts ruled a variety of United Shoe's practices illegal including its use of a lease-only policy (see Kaysen (1956) for a discussion). In 1956 IBM agreed to a Justice Department consent decree requiring it to discontinue its lease-only policy (see Soma (1976) and Fisher, McGowan, and Greeenwood (1983) for discussions). 
As a final point, one qualification to this conclusion is that such a prohibition may not be optimal in certain cases because of other distortions that would be created. For example, I do not think it is feasible for the government to intervene in the textbook market and require firms to introduce new products less frequently. There are a number of factors that come into play in terms of the decision to introduce a new version of a textbook, and government intervention concerning this decision is likely to cause more problems than it would solve. Another example concerns the lease-only policy. Although I believe that intervening in the United Shoe, IBM, and Xerox cases was the correct decision in each case, there was a potential downside with those interventions. That is, to the extent that a firm unable to use lease-only responds by building less durability into its new units (this is a potential response since in this argument lease-only and reduced durability are substitute ways to reduce the availability of used units), it is possible that a prohibition on lease-only could result in decreased rather than increased social welfare.

\section{TYING GIVEN DURABILITY, SWITCHING COSTS, AND UPGRADES}

Because of the recent attention paid to Microsoft's behavior and, in particular, its tying of various products including Internet Explorer with Windows, there has been significant theoretical attention paid to the tying of complementary goods by firms with significant market power. Most of these analyses do not focus on the durable nature of Microsoft's products and the fact that Microsoft introduces upgraded products over time. In this section I describe recent research I have been conducting with Dennis Carlton that focuses on the tying of complementary goods in durable-goods markets given switching costs and product upgrades, where our analysis of upgrades builds on analyses of new-product introductions such as the analysis of Fudenberg and Tirole (1998) discussed in Section III. As I will describe, the basic conclusion of our analysis is that, in the presence of product durability, switching costs, and product upgrades, tying in order to foreclose competition in the tied market is profitable in a broader set of circumstances than the previous literature suggests.

The classic analysis of tying used to foreclose competition in the tied market is Whinston (1990). Whinston shows that in contrast to what had been argued previously by a number of authors connected to the "Chicago School," there are situations in which a monopolist of a primary product will tie a second product to the primary product in order to foreclose competition in the tied market market and in this way increase the firm's profitability in that market. ${ }^{14}$ Focusing on his analysis of complementary goods,

In 1975 Xerox and the Federal Trade Commission entered into a consent decree that stated that Xerox was violating the antitrust laws though its used of a lease-only policy.

14 In particular, Director and Levi (1956), Bowman (1957), Posner (1976), and Bork (1978) all argued that a monopolist of a primary product never has an incentive to tie a complementary product in order to monopolize the complementary market. Their argument was that the primary-good monopolist could capture all the potential monopoly profits in the complementary market through its sales of the primary good. Whinston's paper formalizes 
however, Whinston shows that this result never holds when the monopolist's primary good is "essential," i.e., when the monopolist's primary product is required for all uses of the complementary good. This is problematic from the standpoint of understanding Microsoft's behavior because, to the extent Microsoft has or had a monopoly in the operating systems market, then Whinston's analysis indicates little or no return to Microsoft from a foreclosure standpoint for bundling applications programs with Windows.

One approach to resolving this puzzle is to move attention away from the primary-good monopolist capturing profits in the complementary market to the primary-good monopolist preserving its primary-market monopoly and extending this monopoly to newly-emerging markets. ${ }^{15}$ This possibility was analyzed in Carlton and Waldman (2002) (see also Choi and Stefanidis (2001)). That paper considered a series of models that show how a primary-good monopolist can use tying to both preserve and extend its primary-good monopoly. For example, we considered a two-period model in which an alternative producer has a superior complementary product, can enter the complementary market in either period, but can only enter the primary market in the second period. We showed that, if the alternative producer has costs of entering both primary and complementary markets, then there are parameterizations in which the monopolist ties in order to preserve its primary-good monopoly in the second period. The logic is that tying reduces the incentive for the alternative producer to enter the complementary market by eliminating any first-period sales, and this reduced incentive for the alternative producer to enter the complementary market results in the alternative producer not entering either market in the second period.

We believe that our previous analysis provides a plausible explanation for why Microsoft integrated Explorer into Windows, i.e., many experts thought that a successful browser had the potential to evolve into a substitute for Windows and thus it is plausible that tying was used by Microsoft to preserve its Windows monopoly. But we also feel that this explanation is not plausible for some of Microsoft's other tying decisions. For example, Microsoft recently chose to bundle digital media technology with Windows, but digital media technology does not seem to pose the same threat to Windows as Netscape Navigator did. With this in mind, we have decided to reconsider the question originally asked by Whinston which is, under what circumstances will a monopolist of a primary good tie its complementary good in order to foreclose competition in the tied market and earn monopoly profits in that market? The difference, however, is that in contrast to Whinston we consider a durable-goods setting in which product upgrades are possible and we also consider the possibility of consumer switching costs, i.e., in upgrading a consumer derives a higher gross benefit by not switching brands.

this argument but also shows that it is not valid in all cases, i.e., it is not correct when the tied good is not characterized by constant returns to scale and competition and when the primary or tying good is not essential (see also the earlier work of Ordover, Sykes, and Willig (1985)).

15 Another possibility is that Microsoft ties for efficiency reasons. See, for example, Carlton and Perfloff (1999) for efficiency rationales for tying. 
Before proceeding to the results of our analysis, it is useful to consider the logic behind Whinston's finding that tying is never used to extract rents from the complementary market when the monopolist's primary good is essential. Consider a one-period model in which the monopolist's primary good is essential and in which the alternative producer has a superior complementary product. Let $\mathrm{P}^{*}$ denote the monopolist's optimal bundle price and $\pi^{*}$ monopoly profitability if the monopolist bundles. Now suppose the monopolist does not bundle and sets the price of the primary good at $\mathrm{P}^{*}-\mathrm{c}_{\mathrm{c}}$ and the price of the complementary good at $\mathrm{c}_{\mathrm{c}}$, where $\mathrm{c}_{\mathrm{c}}$ is the marginal cost of the complementary good. Doing this must result in monopoly profitability equal to $\pi^{*}$. Hence, since optimal pricing when the monopolist does not tie must result in profits at least equal to this level, we have that selling individual products yields profits greater than or equal to that with tying so the monopolist has no incentive to tie.

I now discuss what happens in my analysis with Carlton which considers a two-period setting characterized by product upgrades for the complementary good in the second period and potentially consumer switching costs. Also, consistent with the above discussion, we assume the alternative producer has a superior complementary good. We show that in this setting Whinston's result that tying is never optimal when the monopolist's primary good is essential breaks down. We first consider the case in which there are no switching costs and firms sell as opposed to lease or rent their products. In this case the argument breaks down because the monopolist does not sell the primary good in the second period, and thus the monopolist cannot capture the second-period profits associated with the complementarygood upgrade through the pricing of the primary good. The result is that, if the increased product quality associated with the upgrade is sufficiently high, then the monopolist ties because this allows the firm to capture the second-period profits associated with upgrading.

Our second analysis considers what happens when firms can lease as well as sell their products. We begin this analysis by showing that the option to lease eliminates the result just described. That is, if the monopolist can lease, then in the absence of consumer switching costs there is no return to the monopolist to tying. The reason is that leasing allows the monopolist to capture second-period-upgrade profits through the second-period lease price for the primary product. We then introduce switching costs and show that, even with leasing, the monopolist may tie its products. The logic here is that the secondperiod lease price allows the monopolist to capture second-period profits due to the upgrade but does not necessarily allow the monopolist to capture second-period profits associated with the switching costs. The result is that, if switching costs are sufficiently large, then the monopolist ties in order to capture the profits due to the switching costs.

Both of the analyses described above depend on ties being irreversible, i.e., a consumer cannot use the alternative producer's complementary product if the monopolist sells or leases a tied product consisting of primary and complementary goods. Since in the Microsoft situation ties are at least partly if 
not fully reversible, an interesting extension is to consider what happens with reversible ties. Although we have not completed this part of the analysis, our preliminary investigation of this issue suggests that even with reversible ties the monopolist sometimes ties its products. The reason is that tying is a way for the monopolist to commit to a zero price for the complementary good in the second period, and in some cases this is a valuable commitment for the monopolist to make.

Let me end the section with a discussion of antitrust implications. The analysis suggests that the antitrust authorities should be more concerned about the tying of complementary goods than the previous literature suggests. In particular, Whinston's classic paper finds that, if the primary good is essential, then a primary-good monopolist would not have an incentive to tie a complementary good in order to capture profits associated with the complementary market. To the extent Windows is an essential product, this result suggests that many of Microsoft's tying decisions are not driven by a foreclosure motivation so these actions are likely benign from a social-welfare standpoint and should thus be allowed. But Carlton and I show that Whinston's finding is not robust to the introduction of durability, product upgrades, and consumer switching costs - all features of the Microsoft situation. In particular, in such a situation, even if the monopolist's primary good is essential, a monopolist may tie and foreclose a superior complementary product in order to capture profits associated with the complementary-good market. Hence, if these features are present, then tying even when the primary good is essential may be used to foreclose competition in the tied market and thus merits close scrutiny by the antitrust authorities.

\section{AFTERMARKET MONOPOLIZATION IN COMPETITIVE INDUSTRIES}

A series of court cases in the US concerning firms such as Kodak, Data General, Unisys, and Xerox concern the issue of aftermarket monopolization. Aftermarket here refers to the market for a product that is complementary to a durable-goods producer's primary product such as the market for maintaining a particular brand of automobile. The basic issue is whether a durable-goods producer should be allowed to behave in a manner that monopolizes aftermarkets for its own durable products. For example, in Eastman Kodak Co. v. Image Technical Services, Inc., et al. (1992), Kodak was alleged to have monopolized the maintenance markets for its own copiers and micrographic equipment by refusing to sell spare parts to alternative maintenance suppliers. In-depth discussions of aftermarket monopolization appear in Shapiro (1995), Chen, Ross, and Stanbury (1998), and Carlton (2001). Here I discuss recent research I have conducted on this topic.

The issue of aftermarket monopolization has recently received significant theoretical attention because of interest in the Kodak case. In that case the US Supreme Court ruled that, even if Kodak had no market power in the market for new copiers and micrographic equipment, Kodak could still be guilty of having illegally monopolized the maintenance markets for these products. This was a surprising decision standard thinking would have suggested that the efficiency properties associated with 
competition would have resulted in Kodak's behavior in the maintenance markets being ruled legal rather than illegal. The case and the decision prompted a number of industrial organization economists to consider why a competitive durable-goods seller might monopolize an aftermarket for its own product, and the related question of whether the antitrust authorities should or should not allow the behavior.

The previous literature on the subject has focused mostly on a set of related arguments that regard the behavior as some variant of the hold-up problem (see, e.g., Borenstein, Mackie-Mason, and Netz (1995)). ${ }^{16}$ In these arguments consumers are locked into purchasing maintenance once they purchase a new durable unit, and aftermarket monopolization is a way the durable-goods producer exploits these locked-in positions to extract ex post rents. In these analyses there is a social-welfare loss due to the monopoly pricing of maintenance, so these analyses justify the Supreme Court's decision.

The problem with this argument is that it requires either that consumers do not consider the maintenance price in their original decisions to purchase new units, that consumers are surprised, or that contracting to avoid the hold-up problem is not feasible. The reason this is problematic is that none of these possibilities seem likely. On the one hand, the first two possibilities are not likely because in a number of the cases consumers were sophisticated businesses and the cost of maintenance was a significant proportion of the total cost of using the product. On the other hand, the last possibility is not likely because long-term maintenance contracts are quite common in many of the industries in which the monopolization of maintenance markets has been observed.

In Carlton and Waldman (2003) and Morita and Waldman (2003), I put forth along with coauthors a new explanation for the behavior based on an important aspect of the Kodak case (and which has been mentioned as a possible feature in a number of other cases). That is, a feature of a number of cases, including the Kodak case, is that the market is characterized by consumer switching costs. Similar to the usage in the previous section, consumer switching costs here means that when a consumer replaces an old durable unit with a new unit there are costs to the consumer of switching from one firm's product to another's. These costs could arise for a number of reasons such as learning-by-doing and investments in durable complementary goods that become worthless when a consumer changes brands. ${ }^{17}$

\footnotetext{
${ }^{16}$ An alternative argument that has been put forth is that the behavior is used to price discriminate (see Chen and Ross (1993) and Klein (1993)). In this argument, consumers with higher valuations for the durable-goodsproducer's product are heavy users of maintenance, with the result that the seller more effectively price discriminates by monopolizing the maintenance market and increasing the maintenance price. Although Klein argues otherwise, the natural interpretation of this argument is that it provides a clear rationale for aftermarket monopolization by firms with significant market power but has trouble explaining why firms with little or no market power would adopt the practice.

17 The allegations against Kodak in the 1992 case contained a number of detailed accounts of switching costs faced by consumers of Kodak's products. For example,
}

"The system at CSC includes a combination of micrographics machines, and of computer 
The first step of the argument builds on a result found in earlier papers such as Schmalensee (1974), Su (1975) and Rust (1986). Those papers consider durable-goods-monopoly models in which the maintenance market is competititve. Their main finding is that, because the monopolist charges a price for its output that is above its marginal cost of production while maintenance is priced competitively, consumers do not behave in an efficient fashion. Rather, consumers sometimes maintain used units when it would be efficient to replace them. The result is typically a reduction in monopoly profitability because the inefficiency reduces consumer willingness to pay.

The first step of our argument is to show that this basic finding for durable-goods monopoly models also holds when the new-unit market is competitive but there are consumer switching costs. The logic is that, due to the switching costs, a firm selling new replacement durable units has market power when selling to individuals who consumed a unit of the firm's product in the previous period. Hence, if the maintenance market is competitive, the presence of this market power at the date of the replacement decision causes consumers to maintain rather than replace their used units more often than is efficient. Note that one difference between this result and the monopoly result concerns who is hurt by this socialwelfare distortion. As indicated, in the monopoly case typically much of the reduction in social surplus takes the form of decreased monopoly profits. In contrast, because competitive firms earn zero profits in equilibrium, here all of the decreased social surplus takes the form of decreased consumer welfare.

The second step of our argument is to show that the social-welfare distortion concerning the maintenance versus replacement decision is avoided if the seller monopolizes the maintenance market for its own product. If the firm monopolizes the maintenance market, then it will charge an above marginal cost price for both replacement units and maintenance and, more importantly, it maximizes profits at the replacement versus maintenance decision date by pricing in such a way that this decision is made efficiently. Note, however, even though the firm can be thought of as monopolizing the maintenance market in order to maximize profits at the maintenance versus replacement decision date, it is in fact consumers who are made better off when firms are allowed to monopolize the maintenance markets for their own products. That is, since competition means that over the whole course of the game the firms

hardware and software tailored specifically to CSC's needs. Trading its entire equipment for an "interbrand" competitor of Kodak, due to supra-competitive prices, it would be financially unfeasible for CSC. The special software would have to be retailored at a cost of several hundred thousand dollars. Data would have to be reformatted and operators would have to be retrained, again, at a cost of hundreds of thousands of dollars..."

(Plaintiff's Memorandum in Eastman Kodak Co. v. Image Technical Services, Inc. ,et al. (1992), pp. 19-20)

The allegations also state that similar systems to the one described above were found in a variety of places such as "Blue Cross/Blue Shield, insurance companies, banks, and other large financial institutions in many states." (Plaintiff's Memorandum in Eastman Kodak Co. v. Image Technical Services, Inc., et al. (1992), pp. 19-20) 
must earn zero expected profits, when firms monopolize the maintenance markets for their own products and eliminate the maintenance/replacement distortion it is the consumers who are made better off.

From a social-welfare perspective, our analysis yields exactly the opposite conclusion of the hold-up analyses described above. ${ }^{18}$ As discussed, in the hold-up explanation the monopoly pricing of maintenance creates a standard monopoly deadweight loss so monopolization of maintenance markets serves to decrease social wefare. In contrast, in the explanation just described monopolizing the maintenance market increases both consumer welfare and social welfare. Clearly, our analysis suggests that whether or not the courts should allow the behavior depends on which explanation is correct.

As discussed briefly above, there are various reasons why I find the hold-up arguments not plausible in many of the cases in which the behavior has been observed. To be more specific, my feeling is that there is a strong argument that in cases like the Kodak case in which there is clear evidence of consumer switching costs the behavior should be allowed. In such cases theory indicates that competitive maintenance markets do not yield efficient outcomes, so a prohibition that keeps maintenance markets competitive does not seem justified. I would further argue more generally that the antitrust authorities should be hesitant to intervene whenever the market for new durable units is competitive. Theory indicates that competitive-durable-goods producers have a strong incentive to market their products in the fashion that maximizes both consumer welfare and social welfare. So intervention in such markets should only occur when the authorities have a strong and clear case that behavior is not serving societal interests.

\section{CONCLUSION}

Markets for durable goods raise a number of issues that do not arise or arise less frequently in nondurable-goods markets. In turn, these differences between durable- and nondurable-goods markets lead to antitrust issues that are specific to durable-goods markets. For example, a feature specific to durable-goods markets is that of secondhand markets for used units, which leads to the antitrust issue, to

\footnotetext{
18 Schwartz and Werden (1996), Chen and Ross (1999), and Elzinga and Mills (2001) are previous papers that provide efficiency explanations for the behavior. First, Schwartz and Werden develop a signalling explanation for aftermarket monopolization in which high-quality durable units require more of the aftermarket product. Second, Chen and Ross develop an explanation in which free maintenance is bundled with the sale of new durable units, where this stops subsidization of light users of the product by heavy users and thus improves efficiency by moving maintenance towards efficient levels. Third, Elzinga and Mills provide an efficiency role for aftermarket monopoly in an industry in which there are increasing returns to scale in the production of new durable units so that competition is not feasible. I believe that, at least in terms of the Kodak case, the explanation put forth above better matches the evidence, and, in particular, the first and third of these alternatives seem to be a weak fit. In terms of the Schwartz and Werden argument this is because high-quality durable units typically require less not more maintenance, while the Elzinga and Mills argument is inconsistent with the court's focus on Kodak being a competitive producer. More generally, the above argument is the only one that relies on consumer switching costs
} 
what extent should antitrust authorities allow new-unit producers to behave in ways that eliminate secondhand markets by making used units unavailable for consumption? Another example concerns the issue of aftermarket monopolization. Aftermarkets such as markets for maintenance are much more common and important for durable goods than for nondurables. The important antitrust issue here is to what extent should durable-goods sellers be allowed to behave in ways that monopolize the aftermarkets for their own products.

In this paper I briefly reviewed the theoretical literature on durable-goods markets, and then described a number of my own recent analyses concerning optimal antitrust policy for durable-goods markets that mostly build on ideas that appear in the last few years of the larger literature. For example, the classic Swan approach to durable-goods modeling has the unrealistic feature that consumers can combine a number of used units to make a perfect substitute for a new unit. Waldman (1996a) and Hendel and Lizzeri (1999a) have recently explored an alternative approach to modeling durable-goods markets that is not characterized by this feature. In their approach each individual consumes zero or one physical unit per period and durable-good quality decays as a unit ages. In Section IV I discussed the recent paper of Gerstle and Waldman (2004) which shows that optimal antitrust merger policy for durable-goods markets is significantly different in an analysis that employs this new approach.

Another analysis concerns the issue of tying in complementary markets. In a classic paper, Whinston (1990) considers a monopolist of a primary product and shows that, if the primary product is essential, i.e., needed for all uses of a complementary product, then the monopolist would have no incentive to tie its primary and complementary products in order to extend its monopoly to the complementary market. But Whinston considers a one-period setting. In Section VI I describe research in progress with Dennis Carlton that considers this issue in a durable-goods setting. In particular, we consider a two-period setting in which the monopolist's primary good is essential, but in the second period both the monopolist and the alternative producer have the ability to sell a complementary-good upgrade. We show that in this model Whinston's result concerning essential primary goods breaks down, i.e., tying may be used to foreclose competition in the tied market even when the monopolist's primary good is essential. The conclusion I draw from this finding is that antitrust intervention to stop the tying of complementary goods may be justified in more cases than the previous literature suggests.

In summary, there have been significant advances in the theoretical literature on durable goods in recent years, where these advances have significantly moved the literature towards greater realism. The main focus of this paper has been on discussing a number of my own recent analyses that show how one can employ these advances to further our understanding of optimal antitrust policy. But I feel that the

which was clearly an important aspect of the Kodak case and which has also been mentioned as an important aspect of a number of other cases. 
analyses described do not come close to exhausting the implications of these advances for antitrust policy. My hope, therefore, is that in addition to communicating some recent ideas concerning antitrust policy for durable-goods markets, the paper convinces other researchers to focus more on what the recent durablegoods theory literature tells us about optimal antitrust policy.

\section{REFERENCES}

Akerlof, G. 1970. "The Market for 'Lemons': Quality Uncertainty and the Market Mechanism." Quarterly Journal of Economics. 84, pp. 488-500.

Anderson, S. and V. Ginsburgh. 1994. "Price Discrimination via Second-Hand Markets." European Economic Review. 38, pp. 23-44.

Auernheimer, L. and T. Saving. 1977. "Market Organization and the Durability of Durable Goods." Econometrica. 45, pp. 219-228.

Ausubel, L. and R. Deneckere. 1989. "Reputation in Bargaining and Durable Goods Monopoly." Econometrica. 57, pp. 511-531.

Bagnoli, M., S. Salant and J. Swierzbinski. 1989. "Durable-Goods Monopoly with Discrete Demand." Journal of Political Economy. 97, pp. 1459-1478.

Barro, R. 1972. “Monopoly and Contrived Depreciation.” Journal of Political Economy. 80, pp. 589-607.

Benjamin, D. and R. Kormendi. 1974. "The Interrelationship Between the Markets for New and Used Durable Goods." Journal of Law and Economics. 17, pp. 381-401.

Bond, E. and L. Samuelson. 1984. "Durable Good Monopolies with Rational Expectations and Replacement Sales." Rand Journal of Economics. 15, pp. 336-345.

Borenstein, S., J. Mackie-Mason and J. Netz. 1995. "Antitrust Policy in Aftermarkets." Antitrust Law Journal. 63, pp. 455-482.

Bork, R. 1978. The Antitrust Paradox: A Policy at War with Itself. New York: Basic Books.

Bowman, W. 1957. "Tying Arrangements and the Leverage Problem." Yale Law Review. 67, pp. 19-36.

Bulow, J. 1982. “Durable Goods Monopolists.” Journal of Political Economy. 90, pp. 314-332.

Bulow, J. 1986. “An Economic Theory of Planned Obsolescence.” Quarterly Journal of Economics. 101, pp. 729-749.

Butz, D. 1990. "Durable-Good Monopoly and Best-Price Provision." American Economic Review. 80, pp. 1062-1076. 
Carlton, D. 2001. "A General Analysis of Exclusionary Conduct and Refusal to Deal - Why Aspen and Kodak are Misguided." Antitrust Law Journal. 68, pp. 659-683.

Carlton, D. and R. Gertner. 1989. "Market Power and Mergers in Durable Goods Industries." Journal of Law and Economics. 32, pp. 203-226.

Carlton, D. and J. Perloff. 1999. Modern Industrial Organization, $3^{\text {rd }}$ ed. New York: Addison Wesley.

Carlton, D. and M. Waldman. 2002. "The Strategic Use of Tying to Preserve and Create Market Power in Evolving Industries.” Rand Journal of Economics. 33, pp. 194-220.

Carlton, D. and M. Waldman. 2003. "Competition, Monopoly, and Aftermarkets." Mimeo, Cornell University.

Chen, Z. and T. Ross. 1993. "Refusals to Deal, Price Discrimination and Independent Service Organizations.” Journal of Economics and Management Strategy. 2, pp. 593-614.

Chen, Z. and T. Ross. 1999. "Refusals to Deal and Orders to Supply in Competitive Markets." International Journal of Industrial Organization. 17, pp. 399-417.

Chen, Z., T. Ross and W. Stanbury. 1998. "Refusals to Deal and Aftermarkets." Review of Industrial Organization. 13, pp. 131-151.

Choi, J. 1994. "Network Externality, Compatibility Choice, and Planned Obsolescence.” Journal of Industrial Economics. 42, pp. 167-182.

Choi, J. and C. Stefanadis. 2001. “Tying, Investment, and the Dynamic Leverage Theory.” Rand Journal of Economics. 32, pp. 52-71.

Coase, R. 1972. "Durability and Monopoly.” Journal of Law and Economics. 15, pp. 143-149.

DeGraba, P. 1994. "No Lease is Short Enough to Solve the Time Inconsistency Problem." Journal of Industrial Economics. 42, pp. 361-374.

Director, A. and E. Levi. 1956. "Law and the Future: Trade Regulation." Northwestern University Law Review. 51, pp. 281-296.

Ellison, G. and D. Fudenberg. 2000. “The Neo-Luddite's Lament: Excessive Upgrades in the Software Industry.” Rand Journal of Economics. 31, pp. 253-277.

Elzinga, K. and D. Mills. 2001. "Independent Service Organizations and Economic Efficiency." Economic Inquiry. 39. pp. 549-560.

Farrell, J. and C. Shapiro. 1988. "Dynamic Competition with Switching Costs." Rand Journal of Economics. 19, pp. 123-137.

Farrell, J. and C. Shapiro. 1989. “Optimal Contracts with Lock-In.” American Economic Review. 79, pp. 51-68.

Fisher, F, J. McGowan and J. Greenwood. 1983. Folded, Spindled and Mutilated: Economic Analysis 
and U.S. v. IBM. Cambridge, MA: MIT Press.

Fishman, A. and R. Rob. 2000. "Product Innovation by a Durable-Good Monopoly." Rand Journal of Economics. 31, pp. 237-252.

Froeb, L. 1989. "Evaluating Mergers in Durable Good Industries.” The Antitrust Bulletin. 34, pp. 99-119.

Fudenberg, D. and J. Tirole. 1998. "Upgrades, Tradeins, and Buybacks.” Rand Journal of Economics. 29, pp. 235-258.

Gerstle, A. and M. Waldman. 2004. "Mergers in Durable-Good Industries: A Re-Examination of Market Power and Welfare Effects." Mimeo, Cornell University.

Gul, F., H. Sonnenschein and R. Wilson. 1986. "Foundations of Dynamic Monopoly and the Coase Conjecture.” Journal of Economic Theory. 39, pp. 155-190.

Hendel, I. and A. Lizzeri. 1999a. "Interfering with Secondary Markets." Rand Journal of Economics. 30, pp. 1-21.

Hendel, I. and A. Lizzeri. 1999b. “Adverse Selection in Durable Goods Markets.” American Economic Review. 89, pp. 1097-1115.

Hendel, I. and A. Lizzeri. 2002. “The Role of Leasing Under Adverse Selection.” Journal of Political Economy. 110, pp. 113-143.

Johnson, J. and M. Waldman. 2003. "Leasing, Lemons, and Buybacks." Rand Journal of Economics. 34, pp. 247-265.

Johnson, J. and M. Waldman. 2004. “Leasing, Lemons, and Moral Hazard.” Mimeo, Cornell University.

Kahn, C. 1986. "The Durable Goods Monopolist and Consistency with Increasing Costs." Econometrica. 42, pp. 289-301.

Karp, L. and J. Perloff. 1996. "The Optimal Suppression of a Low-Cost Technology by a Durable-Good Monopoly.” Rand Journal of Economics. 27, pp. 346-364.

Kaysen, C. 1956. United States v. United Shoe Machinery Corporation: An Economic Analysis of an Antitrust Case. Cambridge, MA: Harvard University Press.

Kim, J. 1989. “Trade in Used Goods and Durability Choice.” International Economic Journal. 3, pp. 5363.

Kleiman, E. and T. Ophir. 1966. "The Durability of Durable Goods.” Review of Economic Studies. 33, pp. $165-178$.

Klein, B. 1993. "Market Power in Antitrust: Economic Analysis After Kodak." Supreme Court Economic Review." 3, pp. 43-92.

Klemperer, P. 1987. "Markets with Consumer Switching Costs." Quarterly Journal of Economics. 102, pp. 375-394. 
Klemperer, P. 1989. "Price Wars Caused by Switching Costs." Review of Economic Studies. 56, pp. 405420.

Klemperer, P. 1995. "Competition when Consumers have Switching Costs: An Overview with Applications to Industrial Organization, Macroeconomics, and International Trade." Review of Economic Studies. 62, 515-539.

Lee, I. and J. Lee. 1998. “A Theory of Economic Obsolescence.” Journal of Industrial Economics. 46, pp. 383-401.

Levhari, D. and T. Srinivasan. 1969. "Durability of Consumption Goods: Competition versus Monopoly." American Economic Review. 59, pp. 102-107.

Levine, D. and W. Pesendorfer. 1995. "When are Agents Negligible?" American Economic Review. 85, pp. 1160-1170.

Levinthal, D. and D. Purohit. 1989. "Durable Goods and Product Obsolescence.” Marketing Science. 8, pp. 35-56.

Liebowitz, S. 1982. "Durability, Market Structure, and New-Used Goods Models." American Economic Review. 72, pp. 816-824.

Masten, S. and E. Snyder. 1993. "United States versus United Shoe Machinery Corporation: On the Merits." Journal of Law and Economics. 36, pp. 33-70.

Miller, H. 1974. "On Killing Off the Market for Used Textbooks and the Relationship Between Markets for New and Used Secondhand Goods." Journal of Political Economy. 82, pp. 612-619.

Morita, H. and M. Waldman. 2003. "Competition, Monopoly Maintenance, and Consumer Switching Costs.” Mimeo, Cornell University.

Morita, H. and M. Waldman. 2004. "Competition, Monopoly Maintenance, and Consumer Switching Costs." Journal of Economics and Management Strategy. 13, pp. 273-302.

Mussa, M. and S. Rosen. 1978. "Monopoly and Product Quality.” Journal of Economic Theory. 18, pp. 301-317.

Nahm, J. 2004. "Durable Goods Monopoly with Endogenous Innovation." Journal of Economics and Management Strategy. 13, pp. 303-319.

Ordover, J., A. Sykes and R. Willig. 1985. "Nonprice Anticompetitive Behavior by Dominant Firms Toward the Producers of Complementary Products." In F. Fisher, ed., Antitrust and Regulation: Essays in Memory of John J. McGowan. Cambridge, MA: MIT Press.

Plaintiff's Memorandum in Eastman Kodak Co. v. Image Technical Services, Inc., et al., 1992.

Posner, R. 1976. Antitrust Law: An Economic Perspective. Chicago: University of Chicago Press.

Reitman, D. 2001. "Mergers in Durable Good Markets with Rational Consumers." U.S. Department of 
Justice, Antitrust Division, Economic Analysis Group Discussion Paper, EAG 01-8.

Rust, J. 1986. "When is it Optimal to Kill off the Market for Used Durable Goods." Econometrica. 54, pp. 65-86.

Schmalensee, R. 1970. "Regulation and the Durability of Goods.” Bell Journal of Economics. 1, pp. 5464.

Schmalensee, R. 1974. "Market Structure, Durability, and Maintenance Effort." Review of Economic Studies. 41, pp. 277-287.

Schmalensee, R. 1979. "Market Structure, Durability, and Quality: A Selective Survey." Economic Inquiry. 17, pp. 177-196.

Schwartz, M. and G. Werden. 1996. "A Quality Signalling Rationale for Aftermarket Tying." Antitrust Law Journal. 64, pp. 387-404.

Shapiro, C. 1995. "Aftermarkets and Consumer Welfare: Making Sense of Kodak." Antitrust Law Journal. 63, pp. 483-511.

Sieper, E. and P. Swan. 1973. "Monopoly and Competition in the Market for Durable Goods." Review of Economic Studies. 40, pp. 333-351.

Soma, J. 1976. The Computer Industry. Lexington, MA: Lexington Books.

Stokey, N. 1981. "Rational Expectations and Durable Goods Pricing." Bell Journal of Economics. 12, pp. 112-128.

Su, T. 1975. "Durability of Consumption Goods Reconsidered." American Economic Review. 65, pp. 148-157.

Swan, P. 1970. "Durability of Consumption Goods.” American Economic Review. 60, pp. 884-894.

Swan, P. 1971. "The Durability of Goods and Regulation of Monopoly." Bell Journal of Economics. 2, pp. 347-357.

Swan, P. 1972. "Optimum Durability, Second Hand Markets, and Planned Obsolescence." Journal of Political Economy. 80, pp. 575-585.

Swan, P. 1980. "Alcoa: The Influence of Recycling on Monopoly Power." Journal of Political Economy. 88, pp. 76-99.

Waldman, M. 1993. “A New Perspective on Planned Obsolescence." Quarterly Journal of Economics. 108, pp. 273-283.

Waldman, M. 1996a. “Durable Goods Pricing When Quality Matters.” Journal of Business. 69, pp. 489510.

Waldman, M. 1996b. "Planned Obsolescence and the R\&D Decision." Rand Journal of Economics. 27, pp. 583-595. 
Waldman, M. 1997. "Eliminating the Market for Secondhand Goods." Journal of Law and Economics. 40, pp. 61-92.

Waldman, M. 2003. "Durable Goods Theory for Real World Markets.” Journal of Economic Perspectives. 17, pp. 131-154.

Whinston, M. 1990. “Tying, Foreclosure, and Exclusion.” American Economic Review. 80, pp. 837-859.

Wicksell, K. 1934. Lectures on Political Economy, vol. 1. London: Routledge \& Kegan Paul.

Wiley, J., E. Rasmusen and M. Ramseyer. 1990. “The Leasing Monopoly.” UCLA Law Review. 37, pp. 693-731.

Williamson, O. 1975. Markets and Hierarchies: Analysis and Antitrust Implications. New York: The Free Press.

Williamson, O. 1985. The Economic Institutions of Capitalism: Firms, Markets, Relational Contracting. New York: The Free Press. 


\title{
CESifo Working Paper Series
}

\author{
(for full list see www.cesifo.de)
}

1245 Rafael Lalive and Alois Stutzer, Approval of Equal Rights and Gender Differences in Well-Being, July 2004

1246 Paolo M. Panteghini, Wide vs. Narrow Tax Bases under Optimal Investment Timing, July 2004

1247 Marika Karanassou, Hector Sala, and Dennis J. Snower, Unemployment in the European Union: Institutions, Prices, and Growth, July 2004

1248 Engin Dalgic and Ngo Van Long, Corrupt Local Government as Resource Farmers: The Helping Hand and the Grabbing Hand, July 2004

1249 Francesco Giavazzi and Guido Tabellini, Economic and Political Liberalizations, July 2004

1250 Yin-Wong Cheung and Jude Yuen, An Output Perspective on a Northeast Asia Currency Union, August 2004

1251 Ralf Elsas, Frank Heinemann, and Marcel Tyrell, Multiple but Asymmetric Bank Financing: The Case of Relationship Lending, August 2004

1252 Steinar Holden, Wage Formation under Low Inflation, August 2004

1253 Ngo Van Long and Gerhard Sorger, Insecure Property Rights and Growth: The Roles of Appropriation Costs, Wealth Effects, and Heterogeneity, August 2004

1254 Klaus Wälde and Pia Weiß, International Competition, Slim Firms and Wage Inequality, August 2004

1255 Jeremy S. S. Edwards and Alfons J. Weichenrieder, How Weak is the Weakest-Link Principle? On the Measurement of Firm Owners' Control Rights, August 2004

1256 Guido Tabellini, The Role of the State in Economic Development, August 2004

1257 François Larmande and Jean-Pierre Ponssard, EVA and the Controllability-congruence Trade-off: An Empirical Investigation, August 2004

1258 Vesa Kanniainen and Jenni Pääkkönen, Anonymous Money, Moral Sentiments and Welfare, August 2004

1259 Panu Poutvaara and Andreas Wagener, Why is the Public Sector More Labor-Intensive? A Distortionary Tax Argument, August 2004

1260 Lars P. Feld and Stefan Voigt, Making Judges Independent - Some Proposals Regarding the Judiciary, August 2004 
1261 Joop Hartog, Hans van Ophem, and Simona Maria Bajdechi, How Risky is Investment in Human Capital?, August 2004

1262 Thomas Eichner and Rüdiger Pethig, Efficient Nonanthropocentric Nature Protection, August 2004

1263 David-Jan Jansen and Jakob de Haan, Look Who's Talking: ECB Communication during the First Years of EMU, August 2004

1264 David F. Bradford, The X Tax in the World Economy, August 2004

1265 Hans-Werner Sinn, Migration, Social Standards and Replacement Incomes. How to Protect Low-income Workers in the Industrialized Countries against the Forces of Globalization and Market Integration, August 2004

1266 Wolfgang Leininger, Fending off one Means Fending off all: Evolutionary Stability in Submodular Games, August 2004

1267 Antoine Bommier and Bertrand Villeneuve, Risk Aversion and the Value of Risk to Life, September 2004

1268 Harrie A. A. Verbon and Lex Meijdam, Too Many Migrants, Too Few Services: A Model of Decision-making on Immigration and Integration with Cultural Distance, September 2004

1269 Thomas Eichner and Rüdiger Pethig, Economic Land Use, Ecosystem Services and Microfounded Species Dynamics, September 2004

1270 Federico Revelli, Performance Rating and Yardstick Competition in Social Service Provision, September 2004

1271 Gerhard O. Orosel and Klaus G. Zauner, Vertical Product Differentiation When Quality is Unobservable to Buyers, September 2004

1272 Christoph Böhringer, Stefan Boeters, and Michael Feil, Taxation and Unemployment: An Applied General Equilibrium Approach, September 2004

1273 Assaf Razin and Efraim Sadka, Welfare Migration: Is the Net Fiscal Burden a Good Measure of its Economics Impact on the Welfare of the Native-Born Population?, September 2004

1274 Tomer Blumkin and Volker Grossmann, Ideological Polarization, Sticky Information, and Policy Reforms, September 2004

1275 Katherine Baicker and Nora Gordon, The Effect of Mandated State Education Spending on Total Local Resources, September 2004

1276 Gabriel J. Felbermayr and Wilhelm Kohler, Exploring the Intensive and Extensive Margins of World Trade, September 2004 
1277 John Burbidge, Katherine Cuff and John Leach, Capital Tax Competition with Heterogeneous Firms and Agglomeration Effects, September 2004

1278 Joern-Steffen Pischke, Labor Market Institutions, Wages and Investment, September 2004

1279 Josef Falkinger and Volker Grossmann, Institutions and Development: The Interaction between Trade Regime and Political System, September 2004

1280 Paolo Surico, Inflation Targeting and Nonlinear Policy Rules: The Case of Asymmetric Preferences, September 2004

1281 Ayal Kimhi, Growth, Inequality and Labor Markets in LDCs: A Survey, September 2004

1282 Robert Dur and Amihai Glazer, Optimal Incentive Contracts for a Worker who Envies his Boss, September 2004

1283 Klaus Abberger, Nonparametric Regression and the Detection of Turning Points in the Ifo Business Climate, September 2004

1284 Werner Güth and Rupert Sausgruber, Tax Morale and Optimal Taxation, September 2004

1285 Luis H. R. Alvarez and Erkki Koskela, Does Risk Aversion Accelerate Optimal Forest Rotation under Uncertainty?, September 2004

1286 Giorgio Brunello and Maria De Paola, Market Failures and the Under-Provision of Training, September 2004

1287 Sanjeev Goyal, Marco van der Leij and José Luis Moraga-González, Economics: An Emerging Small World?, September 2004

1288 Sandro Maffei, Nikolai Raabe and Heinrich W. Ursprung, Political Repression and Child Labor: Theory and Empirical Evidence, September 2004

1289 Georg Götz and Klaus Gugler, Market Concentration and Product Variety under Spatial Competition: Evidence from Retail Gasoline, September 2004

1290 Jonathan Temple and Ludger Wößmann, Dualism and Cross-Country Growth Regressions, September 2004

1291 Ravi Kanbur, Jukka Pirttilä and Matti Tuomala, Non-Welfarist Optimal Taxation and Behavioral Public Economics, October 2004

1292 Maarten C. W. Janssen, José Luis Moraga-González and Matthijs R. Wildenbeest, Consumer Search and Oligopolistic Pricing: An Empirical Investigation, October 2004

1293 Kira Börner and Christa Hainz, The Political Economy of Corruption and the Role of Financial Institutions, October 2004 
1294 Christoph A. Schaltegger and Lars P. Feld, Do Large Cabinets Favor Large Governments? Evidence from Swiss Sub-Federal Jurisdictions, October 2004

1295 Marc-Andreas Mündler, The Existence of Informationally Efficient Markets When Individuals Are Rational, October 2004

1296 Hendrik Jürges, Wolfram F. Richter and Kerstin Schneider, Teacher Quality and Incentives: Theoretical and Empirical Effects of Standards on Teacher Quality, October 2004

1297 David S. Evans and Michael Salinger, An Empirical Analysis of Bundling and Tying: Over-the-Counter Pain Relief and Cold Medicines, October 2004

1298 Gershon Ben-Shakhar, Gary Bornstein, Astrid Hopfensitz and Frans van Winden, Reciprocity and Emotions: Arousal, Self-Reports, and Expectations, October 2004

1299 B. Zorina Khan and Kenneth L. Sokoloff, Institutions and Technological Innovation During Early Economic Growth: Evidence from the Great Inventors of the United States, 1790 - 1930, October 2004

1300 Piero Gottardi and Roberto Serrano, Market Power and Information Revelation in Dynamic Trading, October 2004

1301 Alan V. Deardorff, Who Makes the Rules of Globalization?, October 2004

1302 Sheilagh Ogilvie, The Use and Abuse of Trust: Social Capital and its Deployment by Early Modern Guilds, October 2004

1303 Mario Jametti and Thomas von Ungern-Sternberg, Disaster Insurance or a Disastrous Insurance - Natural Disaster Insurance in France, October 2004

1304 Pieter A. Gautier and José Luis Moraga-González, Strategic Wage Setting and Coordination Frictions with Multiple Applications, October 2004

1305 Julia Darby, Anton Muscatelli and Graeme Roy, Fiscal Federalism, Fiscal Consolidations and Cuts in Central Government Grants: Evidence from an Event Study, October 2004

1306 Michael Waldman, Antitrust Perspectives for Durable-Goods Markets, October 2004 